Teosofia: Indonesian Journal of Islamic Mysticism

Volume 6, Number 2, 2017: 141-152 DOI: 10.21580/tos.v6i2.3407

\title{
The Spirituality of Music in The Light of al-Sarrāj and al-Hujwïrī
}

\author{
Luthfi Rahman \\ Universitas Islam Negeri Walisongo, Semarang - Indonesia \\ luthfirahman@walisongo.ac.id
}

\begin{abstract}
This paper discusses spiritual and fiqh (Islamic Jurisprudence) aspects of music in relation to two classical Sufi masters i.e, Abū Nașr al-Sarräj al-Ṭüsi (378/988) and Ali b. Uthmān al-Jullabi al-Hujwiri (465/1072). It particularly focuses on their two masterpieces i.e., Kitāb al-Luma' and Kashfu al-Mahjūb. It further compares three specific points; permissibility of music, listening to Quran and poetry and the state of ecstasy in auditing music. Based on this study, it is found that the Sufi Masters observed the matter of spirituality can be combined and approached with strict obedience through rigidly practicing fiqh. Yet, it should be noted that spirituality of music will be of course beyond dicta of jurisprudence by the fact that spirituality is inward thing while shari'ah (which is narrowly used to point religious law) is outward one. As to the matter of listening to Quran and poetry, both sufi masters offer more emphasis on listening Qur'an than poetry or odes. Nevertheless, they did not negate the importance of listening poetry, poems and odes. It is evidenced by a hadith stating that indeed there is wisdom in every poetry. In terms of the state of ecstasy, the two masters offer tawajud (artificial wajd). Tawajud is aimed to gain wajd by representing to one's mind the bounties and evidences of God, and thinking of union (ittihäd) and wishing for the practices of Muslim saints.
\end{abstract}

Keywords: spirituality of music; al-Sarrāj; al-Hujwìiri; al-Luma'; Kashfu al-Mahjūub

\section{A. Introduction}

"Know that hearts and consciences are treasuries of secrets and mines of jewels. Wrapped within them lie their jewels just as fire is enveloped iniron and stone, and hidden like water is concealed under dust and loam.There is no way of extracting such hidden things save by the flint and steel of audition to poetry and music (Sama), and there is no entrance to the heart save by the ante chamber of the ears. So musical tones, measured and pleasing, bring forth what is in it and make evident its beauties and defects." Abu Hamid al-Ghazali (n.d.: 23, also cf. MacDonald 1901-2a: 199). 
A

quotation above is somewhat an allusion to show that samā' (audition) is influential for certain state of heart. Samä' is a part of ways to achieve spirituality. It is usually translated into music and chanting. Hence, its existence for many - especially for Islamic jurist and Sufis - is still controversial since it results various effects. For them who do not allow it, they argue that Samā' (audition) would arouse base instincts and has association with drinking parties and immoral activities.

It is often assumed that Islam generally bans music, but this is a very superficial understanding. Even if restrictions have regularly been imposed, it is frequently stressed that the Qur'an does not simply forbid music. While it is a contested matter and subject to interpretation, it is clear that music has been a close companion, and folktales, literature, organological history, iconography and paintings all point to the repeated presence of music in the Islamic world; in short, musical performance has always held a strong position in the history and development of Islam as a global religion. Significantly, when Islam spread to the Iberian Peninsular in the eighth century the first music school in Europe was founded in Cordoba by the learned Ziryab, who also brought the oudto $\mathrm{Al}$ Andalous. ${ }^{1}$

The dictum of the so-called haram/halal dichotomy in music within Islamic jurisprudence discourse according to some classical Muslim scholars/ulama is often rather confusing, as it is neither a rule nor a law. Nevertheless, it clearly refers to the overall compartmentalization of Muslim life, which assists believers in determining whether an activity is good or bad, and is of great importance to the handling of music and dance.

These distinctions rest on a number of social features, popularly ranked under the concepts of zamān (time), makān (place) and ikhwān (associates). Even if the haram/halal distinction is not accepted as law, it is interesting from our point of view that the social 'organisers' of time, place and company in fact create a hierarchy of genres of musical sound, stretching from activities which are Halal, i.e. permissible or legitimate, over controversial phenomena, to those areas of musical life that are explicitly forbidden, i.e. Haram. The most conspicuous example of this interpretive and social definition is perhaps the chanting of the daily prayers and the reading of the Qur' an - the qir'ah, which to Western ears sounds like singing, but is regarded in Islamic thought as 'reading'; it is 'non-musiqa' and therefore permissible.

Beside qur'anic chant, there are three more levels constituting permissible kinds of aural art. This includes family and celebration music, such as lullabies, women's songs and music for weddings, caravan chants, shepherd songs and work songs, and finally military music. Just below the line between legitimate and the questionable forms of

${ }^{1}$ Amnon Shiloah, Music in the World of Islam: A Socio-Cultural Study (London: Scholar Press, 1995), 74 
The Spirituality of Music ....

music, the upper part consists of free, rhythm vocal and instrumental improvisations, as for instance the taksims. As they stylistically resemble qur'anic chant, they are generally - but not universally - accepted. Below the level of such improvisations are metered vocal and instrumental compositions such as the bashraf - a slow opening movement used all over the Muslim musical world. At the bottom of the questionable level is music of pre-Islamic or non-Islamic origin; folk music or imported modern music. Finally, the lowest level is that of sensuous music, performed in association with condemned activities. This area is clearly and unanimously condemned.

In term of Sufism, samā' is regarded mostly by Sūfis as a media for reinforcing ecstasy and inducing mystical trance. They preserve certain melodies and rhythms to prepare the soul for a deeper comprehension of the divine realities and a better appreciation of divine music. Music, ${ }^{2}$ like other beautiful things, portrays the Șūfi closer to God, who is the source of beauty. It softens the physical realm into the spiritual one by shining the heart and boosting the spiritual aspect of the human being over the physical being. ${ }^{3}$ However not all schools emphasize this.

In more explanative arguments, Jean-Louis Michon marks that music is composed of corporeal and spiritual elements. Since it has dual composition, the art of music possesses the special power of liberating matter in order to spiritualize it and of materializing the spiritual in order to render it audible. ${ }^{4}$

According to Ikhwān al-Safā, ${ }^{5}$ something which typifies and differentiates music from other arts is that the substance upon which it works - the soul of listeners - notes and rhythms is of a subtle nature and not corporeal. There are many examples of emotional states which melodies are capable of inspiring in man, such as regret and repentance for past mistakes, courage in battle, relief from suffering and joyful excitation. $^{6}$

\footnotetext{
${ }^{2}$ Generally speaking, music means the art and science of combining vocal and instrumental sounds or tones to form a wide variety of structurally, aesthetically, and emotionally satisfying expressions of a culture's underlying belief system. It was borrowed from the Greek language by the Muslims of the eight to tenth centuries, the term müsiqa had various connotations in Islamic history. In most instance, it covers only certain secular musical genres of the culture. There are other terms possessed by Arabic to show similar meaning of music; ghinā, samā', tatrīib, and lahw. From those term, the only term to denote the vocal and instrumental music used in the context of $d h i k r$ (remembrance of God) rituals of the Süûi or mystical brotherhoods. L.L. al-Faruqi. Islam and Art (National Hijra Council: Islamabad, 1985), 177.

${ }^{3}$ http://www.britannica.com/EBchecked/topic/520198/sama (Accessed on March 30).

${ }^{4} J$ ean-Louis Michon, "Sacred music and dance in Islam". In World Spirituality, Volume XX, Edited by. Seyyed Hossein Nasr, (The Crossroad Publising Company: New York, 1991), 470.

${ }^{5}$ Theywere a secret society of Muslim philosophers in Basra, Iraq, in the 10th century CE.

${ }^{6}$ Ibid., see also Muhammad Zaki Mubarok. al-Tasawwuf al-Islāmi, Chapter II. (Dār al-Jayl: Beirut Lebanon), 189. Zakirefered to al-Ikhwan al-Safa that music is able to make hearts and souls educated ( tathqīf al-qulūb wa al-arwāh).
}

Teosofia: Indonesian Journal of Islamic Mysticism, Volume 6, Number 2, 2017 
This paper tries to delineate samā' discourse with regard to the two șufi masters namely Abu Nasr al-Sarrāj and Hujwiri. The first is a Șüfi master who lived in Persia writing Kitāb al-Luma' as his masterpiece in Sufism in $10^{\text {th }}$ century, while the latter is a sufi master in the early of $11^{\text {th }}$ century who resided also in Persia whose work was named by Kashf al-Mahjüb. This work will focus on comparative thoughts of both sufi masters -as written in their works - regarding some points of samā' covering basic argument of permissibility, listening Qur' an and poetry and the state of wajd. Those points are picked up in order to get comprehensible depiction related to Islamic spirituality.

\section{B. Al-Sarrāj and Al-Hujwīin in Samā' discourse}

This sub topic pictures the biographies of those two authors in order to know their background in Sufism. In addition, it also comes up with comparative reading in some points taken up from the chapter of audition ${ }^{7}$ :

Kitāb al-Luma' fi 'I-Tașawwuf was written by the Sunni ascetic and scholar namely Abu Nasr Abdallah b. Ali b. Muhammad b. Yahya al-Sarrāj al-Tusi. Sarrāj -his famous call name - passed away in Tus in 378/988. The time he lived was the reign in which Sufis school of Khurasan flowered. ${ }^{8}$ As stated by RA. Nicholson, the evidence about his biography was little found since the authors of the oldest Sufi lives passed him over in silence. The life of his family was notably ascetic. He was a keen scholar of Sunni who based himself on knowledge of the religious law. Hence, he was learned in mystical theology and was regarded by the Sufis as an authoritative exponent of their doctrines. He was celebrated for nobleness of soul. Kitāb al-Luma' records his meetings and conversations with Sufis in many parts of Muhammadan empires i.e. Basra, Baghdad, Damascus, Ramla, Antioch, Tyre, Atrabulus, Cairo, Dimyat, Bistam, Tustar and Tabriz. ${ }^{9}$ One of his grand Sufi masters as stated by SeyyedHosayn Nasr is IbnKhafif. ${ }^{10}$

\footnotetext{
${ }^{7}$ In order to be clear, Sarrāj explores this discussion into several chapters covering audition and various opinions of the Sufis as to its nature, the audition's permissibility to the vulgar (al-'ammah), audition of the elect and their various degrees, different classes of auditors of Qur'an, concerning those who prefer listening to odes and verses of poetry, the audition of novices/ beginners and Sufi shaykhs, the characteristics of the adepts in audition, listening to dhikr, sermons and moral sayings, and concerning those who dislike to be present in places where the Qur'an is recited with musical intonation, or where odes are chanted and the hearers fall into an artificial ecstasy and begin to dance. Otherwise, Hujwiri gives less deep discussion on the audition. He includes several topics; audition of the Koran and kindred matters, audition of the poetry, audition of voices and melodies, the principles of audition, various opinions respecting audition, and concerning their different grades in the reality of audition.

${ }^{8}$ Seyyed Hossein Nasr, "Sufism and Spirituality in Persia" In World Spirituality, Volume XX, Edited by Seyyed Hossein Nasr (The Crossroad Publising Company: New York, 1991), 207.

${ }^{9}$ Sarrāj, AbūNasr. Kitāb al-Lumā 'fi'l-Tașawwüf. Edited for the First Time, with Critical Notes, Abstract of Contents, Glossary, and Indices by ReynoldAlleyne Nicholson, and Printed for the Trustees of the "E. J.W. Gibb Memorial." (Leyden, London: E.J. Brill/ Luzac\& Co, 1914), v.

${ }^{10}$ Ibid. Seyyed Hossein Nasr, 208. His full name is Abu 'Abd Allah Mohammad ibn Khafif ibn Esfakshad was born in Shiraz in 270-271 (882-982). He wasone of the great saints of Persia. He took
} 
The Spirituality of Music ....

He wrote Kitāb al-Luma' since a friend requested him, whose name he does not mention. His aim was to set forth the right doctrines of Sufism and to show by argument and confirmation of the doctrines of Qur'an, prophetic traditions (sunna), and his companions as well as conformity with the religious practice of pious Moslems. ${ }^{11}$ From the biography, I found that he was part of jurists who had deep and remarkable thought in mystical theology.

Kashf al- Mahjūb was originally written in Persian by Ali b. Uthmān al-Jullabi alHujwiri was born around $990 \mathrm{CE}$ and died in (around) 465/1072. His birthday is unknown. He was native of Ghazna in Afghanistan. ${ }^{12}$ He lived during several caliphates of Ghaznavidempire. ${ }^{13} \mathrm{He}$ had several prominent masters such as Abū '1-Qāsim Gurgani $^{14}$ and Khwaja Muzaffar. ${ }^{15} \mathrm{He}$ travelled far and and wide through the Muhammadan empire from Syria to Turkistan and from Indus to Caspian Sea. He was Sunni and a Hanafite. He attempted to bring together his theology with an advanced type of mysticism. ${ }^{16}$

The work itself is similar with al-Luma. It can be seen when expressing his own opinion, the author usually examines the opinions of previous writers, arguing them if it is necessary. In conversing the problems, he illustrated by examples drawn from the

speculative theology (kalām) from al-Ash'ari, jurisprudence (fiqh) from Ibn Surayj, and Sufism (tasawwuf) from Ruwaym, al-Jariri, and Abū al-'Abbās ibn Ațā. Al-Dhahabi said of him, "He is -- one of the most knowledgeable shaykhs in the external sciences ('ulūm al-zāhir)." 'Attạ ${ }^{-}$r, Fari ${ }^{-}$dal $\mathrm{Di}^{-} \mathrm{n}$, and A. J. Arberry. Muslim Saints and Mystics: Episodes from the Tadhkirat al-Auliya' ("Memorial of the Saints") (Boston: Routledge \& Kegan Paul, 1979), 347.

${ }^{11}$ Sarrāj, v.

${ }^{12}$ Hujwirīi, 'A $\overline{l i}$ ibn'Uthmān. Kashf al-Mahjūb. Revelation of the Mystery. Translated by Reynold Alleyne Nicholson (Accord, NY: Pir, 1999), xii.

${ }^{13}$ There were 12 caliphates during his life. The most influential caliphate during his time was Mahmud of Ghazna. Mahmud was celebrated as a hero and a great patron of the arts, architecture, literature, and Persian revivalism as well as a vanguard of Islam and a paragon of virtue and piety who established the standard of Islam in India. http://en.wikipedia.org/wiki/Mahmud_of_Ghazni (accessed on April 8, 2013). But he came from Ghazni to Lahore where he died in the reign of Mas'ud, the son of Mahmud of Ghazna. In this empire, Shafi'ite and Hanafite were prominent schools of Jurisprudence. See Hamid Dabashi, "Historical conditions of Persian Sufism during the Seljuk Period" in The Heritage of Sufism, Volume I. Leonard Lewishon, ed. (One World Publications: oxford, 1999), 137.

${ }^{14} \mathrm{He}$ lived in 380-450 AH and was an Iranian Șüfi of Kubrawiya Șūfi Ṭariqah as well as some

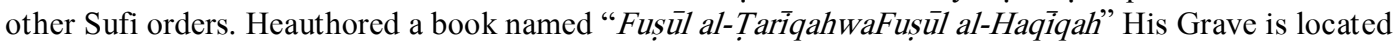
in a small village, three kilometers south of TorbatHeydariyeh in Iran. (www.wikipedia.org accessed April 9, 2013).

${ }^{15} \mathrm{He}$ was also one of his spiritual master whom Hujwiri asked to be his spiritual director when he performed sama'. This story can be read in AnnaSuvorova. Muslim Saints of South Asia (Routledge: New York, 2005), 48.

${ }^{16}$ Hujwīi, Kashf al-Mahjūb, xvii. 
writer's own experience. There is nevertheless a great relieance on the earlier work of Sarraj, as well as on the writings of Sulami ${ }^{17}$ and Qushayri. ${ }^{18}$

\section{Basic argument of Audition's Permissibility}

For the basic argument of allowing audition, both tried to bring their own different references. ${ }^{19}$ Al-Sarraj, in his early chapter of audition explores about the beauty of the voice by referring to the prophets who had fine voices and the Prophet Muhammad owned sweet voice who also liked hear the Qur'an with a musical intonation by his saying "beautify the Qur'an by your voices. ${ }^{20}$ While Hujwiri here remarked at the importance of hearing since it is a means of ascertaining the obligatoriness of knowing God by noticing oral tradition as the very basic manner of transmitting knowledge in the history . As regarded by Sunnis that hearing is more superior than sight in the domain of religious obligation. Furthermore, he said that all religious ordinances are based on hearing and could not be established without it. Whoever denies the audition, he/she also denies the entire religious law. ${ }^{21}$ In this case, it seems that Sarraj tends to refer to the aesthetics of voices as part of God's gift toward human beings embedded in the Prophet and their tendency to like the beautiful voices. Hujwiri founds his argument about the permissibility of audition on the inductive reasoning traced from oral tradition as the way of receiving revelation from God. The characteristic of juridical thought of Hujwiri gives strong nuance in dealing with spirituality.

Besides, the style of these both șufi masters relied on the previous suufis' commentaries. They commented and criticized on them in order to get the commendable arguments from their predecessors. In my point of view, it also symbolizes that spirituality requires valid and authentic references. Accordingly, it also describes the continuous chain of transmission between shaykh and disciple which would later on be formulated by al-Qushayri in his epistles even though in spiritual context, the seed of the importance of shaykh had been firstly claimed by Bayazid al-Bustami ${ }^{22}$ with his statement a person who has no master (spiritual guide) for him, so his master is a satan. "man laisa lahū shaykh fashaykhuhū shaytāñ."

Both require several conditions. Firstly, and most importantly, it is not connected with any evil purpose. Sarrāj claimed further that audition is lawful, if it has no corrupt

\footnotetext{
${ }^{17}$ 'Abd '1-Karimm ibn Hawāzin al-Qushayri, was born in 986-1072 in Nishapur which is in KhorasanProvince in Iran. He was the author of al-Risālah al-Qushayriyya. al-Șūfiyah

${ }^{18} \mathrm{Abu}$ 'Abd '1-Rahmān '1-Sulami lived also in Nishapur 936-1021 and was the author Thabaqāt

${ }^{19}$ They refer firstly to Qur' an and Sunnah. Since sama' is tightly associated with scriptural ethics.

${ }^{20}$ Hujwïiri, Kashf al-Mahjūb, 269.

${ }^{21}$ Ḥujwiri, 394.

${ }^{22} \mathrm{Abu}$ Y Yazid Bisṭāmi (804-874 or 877/8 CE) was a Persian Sufi. He was born in Bastam, Iran.
} 
The Spirituality of Music ....

end in view and if it does not involve the use of certain musical instruments forbidden by the Prophet. His further opinion is based on hadith saying the prohibition of audition with several instruments. There was an 'illah (reason) which endorses the prohibition with those instruments because the instruments at that time were associated with bad people who used to play with them when they were drunken by alcohol, behaving immoral action, etc. ${ }^{23}$ It seems to me that the reason is closely related to the context at that time where the instruments had association with evil and immoral people. It could be understood that the instruments from their substance are not unlawful (haram lidzätihi) but are unlawful because of external factors (harām lighairihi). Of course, in term of spirituality, there is nothing to do with this association since audition and all of its aspects are intended to be a ladder for reaching transcendental intimacy. Indeed, Hujwiri seemed to do nothing with that. It is proven by his certain chapter in audition related to voices and melodies which covers several musical instruments used by some Sufis. $^{24}$

\section{Listening Qur'an and Poetry}

The next interesting topic carried by both is the audition of Qur' an and poetry. Both sufi masters offer more emphasis on listening Qur'an than poetry or odes. Nevertheless, they did not negate the importance of listening poetry, poems and odes. It is evidenced by a hadith stating that indeed there is wisdom in every poetry. In al-Sarraj's point of view, he gives several notions about hearing Qur'an. Qur'an denounces those who listen only with their ears and praises to those who listen with conscientious minds. ${ }^{25}$

There is something interesting in Sarraj's view that might be later on caught by alGhazali with regard to reading poetry sometimes prior to reciting Qur'an. The reasons which escort some Sufis to listen to poetry rather than to Qur'an are written by the author as follows. Qur'an is the Word of God, an eternal attribute of God, which men cannot stand when it appears, because it is uncreated. If God were to reveal it to their hearts as it really is, their hearts would splinter. ${ }^{26}$

As a matter of common knowledge, a man may read the whole Qur'an many times over without being touched with emotion, whereas if the reading is accompanied by a sweet voice and plaintive intonation, he feels emotion and delight in hearing it. These feelings, then, are not caused by Qur'an, but by sweet sounds and melodies which accord with human temperaments. The harmonies of poetry are similar in their nature and their effects and easily blend with music. ${ }^{27}$ Since a certain homogeneity exists between them

\footnotetext{
${ }^{23}$ Sarrāj, Kitāb al-Lumā 'fi'l-Tașawwuf, 277.

${ }^{24}$ Hujwïri, Kashf al-Mahjūb, 399.

${ }^{25}$ Sarrāj, Kitāb al-Lumā 'fi'l-Tasạwwuf, 281.

${ }^{26}$ Sarrāj, 284.

${ }^{27}$ Sarrāj, 285. He added more emphasis that moral sayings can be taken into account as something that probably be utilized in samä, (audition).
}

Teosofia: Indonesian Journal of Islamic Mysticism, Volume 6, Number 2, 2017 
and the spirit of man, their influence is much less powerful and dangerous than that of God's Word. Those who prefer listening to poetry are animated by reverence for Qur'an. ${ }^{28}$

In this matter, Hujwiri did not give any commentaries. It comes to my mind that with regard to listening according to him, listening Qur'an is the most exalted part of audition. Seemingly, Sarraj gives more response toward the development of poetry literatures during the period of Persian Sufis. This view also would have become part of al-Ghazāli's discernment in his Ihyā 'Ulüm al-Dìn. ${ }^{29}$

\section{The Ecstasy (wajd) in Audition}

As a result of audition, it may occur within a person a state of ecstasy since one feels very close with God. Both șufî masters locate the topic of ecstasy in the end of sama' chapter. Wajdis regarded as the peak of spiritual achievement during their audition. Both Sarrāj and Hujwiri concur on this state. According to Sarrāj by referring some previous masters, wajd is every (secret) spiritual feeling of the heart either happy or grief revealed by the God for the believers. ${ }^{30}$ Hujwiri asserts that wajd is a painful affection of the heart, arising either from jest or earnest, either from sadness or gladness ; He who feels wajd is either agitated by ardent longing in the state of occultation (hijäb) or calmed by contemplation in the state of revelation $($ kashf $){ }^{31}$

Nonetheless, it is unique to more attentively look that those two masters offered tawajud (artificial wajd). Tawajud is aimed to gain wajd by representing to one's mind the bounties and evidences of God, and thinking of union (ittihad) and wishing for the practices of holy men. ${ }^{32}$ In my point of view, the state of ecstasy formulated by șufis is an attempt to give broader space as an expression in enjoying the music in the frame of nourishing pleasure of not only human nature but also spiritual intimacy, while tawajudas an artificial way to achieve the state of ecstasy designates that the spiritual enjoyment must be accompanied and put forth through remembrance of God (dhikr).

\footnotetext{
${ }^{28}$ As claimed by Leonard Lewishon, this view is similar to the neo-Platonic theory elaborated by Avicenna in his Kitāb al-Shi' $r$ where, describing the harmony generated by poetry, he states that poetry's "harmony has an unquestionable effect on the soul, and each object has a harmony which suits it best in agreement with its profusion, its sweetness or its moderation; and by this influence the soul reproduces within itself sadness, anger or any other motion." See Leonard Lewishon. "The Sacred Music of Islam: Sama' in the Persian Sufi tradition" in British Journal of Enthomusicology, Vol. 6, British Forum for Ethnomusicology, 1997, p. 33.

${ }^{29}$ It can be found in the chapter of audition (kitab as-sama')

${ }^{30}$ Sarrāj, Kitāb al-Lumā 'fi'l-Tașawwuf, 300.This definition is what I combined from the definitions of wajd introduced by Sarrāj from 'AmribnUthman al-Makki and Junayd.

${ }^{31}$ Hujwīiri, Kashf al-Mahjūub, 414.

${ }^{32}$ Hujwiri, 415.
} 
The Spirituality of Music ....

Sama' 'is not merely beautiful sound to enjoy, but is a type of hikma which can posses a powerful and beneficial influence on hearts. Samā', and dhikr are meaningful incantation and sonorous melodies. Those are reinforced by the author's citing of hikma as a vehicle of samā' along with Qur'anic recitation, poetry. This illustrates the juxtaposition of $d h i k r$ with the divine word. According to him, what is important is the heart's encountering the strong emotion or ecstasy of sacred recollection. It is reawakening the secreted knowledge of the day of covenant or the evoking of essential truth which causes ecstasy and burning of the heart. ${ }^{33}$

Sufi practicing/ auditing music claimed to have influenced their areas of everyday life, and they have obviously grown in popularity during the twentieth century. While they follow Sufi norms differently, according to Fujii they all retain the zikri[dhikr] ritual as their central event. This takes us back to the relationship between music and trance in the dhikr ${ }^{34}$ and to Rouget, who clearly identifies the form as trance and 'not an ecstasy, since it manifests itself by movement [...], is produced by sensorial stimuli (sounds), and is achieved not in solitude, but in the company of other participants' ${ }^{35}$

Rouget further distinguishes between solitary dhikr and collective dhikr. The first is carried out by means of a special way of breathing and is almost silent. The 'collective' dhikr, or dhikr 'of the commoners', is of most interest to us, since it is closely associated with music and dance. ${ }^{36}$ In the practice of the dhikr, according to Rouget, the breath is very important: "The exercise of the Dhikr reaches its paroxysm: faces streaming with sweat, eyes almost closed, the faithful are drawn into a rhythmic frenzy, and then comes the silence of their ecstasy." 37 He concludes, importantly: "as we have seen, in the dhikr in the strict sense it is characteristic for the adepts to be the musicants of their own trance." 38

\section{Conclusion}

Based on elucidating both Sufi masters, it is obvious that sama' (audition) took part as a media to achieve spiritual intimacy. The Sufi masters who were the jurist proved that the matter of spirituality can be combined and approached with strict obedience (religious law). Nevertheless, spirituality will be of course beyond dicta of jurisprudence by the fact that spirituality is inward thing while shari'ah (which is narrowly used to point religious law) is outward one.

${ }^{34}$ Chiaki Fujii, Ritual Activities of Tariqas in Zanzibar (African Study Monographs, 2010), 92.

${ }^{35}$ Gilbert Rouget, Music and Trance: A Theory of the Relations between Music and Possession [1980 French original] (Chicago: University of Chicago Press, 1985), 262.

${ }^{36}$ Rouget, 263.

${ }^{37}$ Rouget, 272.

${ }^{38}$ Rouget. 
It also proves that samā' in across century becomes popular culture within Sufism. It emphasizes that the way of spreading human spirituality through the culture was successfully done. Its success cannot be neglected since the nature of samā' involves transcendental and immanent sides within human personality. From the beginning, early Islamic Șufiss was completely aware of this power of sacred music. Then they tried to find out a compromise how to make it well-used in term of spiritual feeling achievement. This compromising indicates that in some past periods of civilization, music was used to deal with evilness, drunkenness, immorality - as indicated by a prophetic tradition -, then they strove to recall the nature of music as a vehicle for the flight of the soul to God. Its nature is a ladder of the soul to God. It is recognized by SeyyedHosayn Nasr that the sacred music of the Süufis owns the influence to rouse the need soul to travel to the Garden of truth and also to help it along on the journey. ${ }^{39}$

\section{Bibliography}

Ațtāar, Farīdal-Dīn, and A. J. Arberry. Muslim Saints and Mystics: Episodes from the Tadhkirat al-Auliya' ("Memorial of the Saints") Boston: Routledge \& Kegan Paul, 1979.

Dabashi, Hamid. "Historical conditions of Persian Sufism during the Seljuk Period" in The Heritage of SufismVolume I. Leonard Lewishon, ed. One World Publications: Oxford, 1999.

al-Faruqi, L.L. Islam and Art. National Hijra Council: Islamabad, 1985.

Fujii, Chiaki. Ritual Activities of Tariqas in Zanzibar. African Study Monographs, 2010.

Hujwirī', 'Alī ibn'Uthmān. Kashf al-Mahjūb. Revelation of the Mystery. Translated by Reynold Alleyne Nicholson.Accord, NY: Pir, 1999.

http://www.britannica.com/EBchecked/topic/520198/sama (Accessed on March 30)

Lewishon, Leonard, "The Sacred Music of Islam: Sama' in the Persian Sufi tradition" in British Journal of Enthomusicology, Vol. 6, British Forum for Ethnomusicology, 1997.

Michon, Jean-Louis. "Sacred music and dance in Islam". In World Spirituality Volume XX, Edited by. Seyyed Hossein Nasr. The Crossroad Publising Company: New York, 1991.

\footnotetext{
${ }^{39}$ Seyyed Hossein Nasr, The Garden of Truth, The Vision and Promise of Sufism, Islam's Mystical Tradition (Harper Collins Publishers: New York, n.d.), 146.
} 
Mubarok.Muhammad Zaki, al-Tașawwuf al-Islāmi, Chapter II. Dār al-Jayl: Beirut Lebanon.

Nasr, SeyyedHossein. "Sufism and Spirituality in Persia" In World Spirituality Volume XX, Edited by Seyyed Hossein Nasr, The Crossroad Publising Company: New York, 1991.

Nasr, Seyyed Hossein. The Garden of Truth, The Vision and Promise of Sufism, Islam's Mystical Tradition. Harper Collins Publishers: New York, n.d.

Rouget, Gilbert. Music and Trance: A Theory of the Relations between Music and Possession [1980 French original]. Chicago: University of Chicago Press, 1985.

Sarrāj, Abū Nassr. Kitāb Al-Luma 'fi'l-Tasawwuf. Edited for the First Time, with Critical Notes, Abstract of Contents, Glossary, and Indices by ReynoldAlleyne Nicholson, and Printed for the Trustees of the "E. J.W. Gibb Memorial."Leyden, London: E.J. Brill/ Luzac\& Co, 1914.

Shiloah, Amnon. Music in the World of Islam: A Socio-Cultural Study. London: Scholar Press, 1995.

Suvorova, Anna. Muslim Saints of South Asia. Routledge: New York, 2005. 
